\title{
Kantasuomalais-balttilaisten kontaktien tutkimuksen alkuvaiheita
}

\author{
Kirjoitus pohjautuu Suomalais-Ugrilaisessa Seurassa 15. syyskuuta 2006 pidettyyn esitelmään.
}

Tässä artikkelissa käsittelen itämerensuomalais-balttilaisten kontaktien tutkimusta ajanjaksolla, joka ulottuu Jalo Kaliman kirjoittaman alan suomenkielisen oppikirjan ilmestymiseen vuonna 1936. Pro gradu -tutkielmani aiheesta valmistui vuonna 2005. Tavoitteeni työssä oli perehtyä kaikkeen aiheesta mainittuna ajanjaksona ilmestyneeseen kirjallisuuteen. Perehtyminen osoitti, että muilla kielillä kuin suomeksi ja saksaksi julkaistu tutkimus on ollut alalla enimmäkseen marginaalista ja tieteellisesti vähäarvoista ainakin tutkimallani ajanjaksolla, toisin kuin esim. Kari Liukkosen kirjoittaman (1999: 3-5, 9-10) perusteella voisi päätellä.

\section{Vilhelm Thomsen ja tutkimuksen alkuvaiheet}

Alan ensimmäinen ja toistaiseksi merkittävin tutkija, tanskalainen Vilhelm Thomsen julkaisi fennougristiikan alalla kaksi merkkiteosta äidinkielellänsä. Molemmat kirjat ovat ilmestyneet myös saksaksi. Ensimmäinen oli Thomsenin väitöskirja Den gotiske sprogklasses indflydelse på den finske - nykytermein käännettynä 'Germaanisten kielten vaikutus itämerensuomeen' vuodelta 1869. Tässä teoksessa Thomsen loi määritelmän myös itämerensuomalaisten kielten muinaisbalttilaisille lainasanoille. Thomsen (mts. 108) kirjoitti: "litauisk eller et dermed beslægtet sprog (ved siden af en yngre indflydelse af lettisk på livisk) også har øvet en meget stærk påvirkning på hele den finske sprogstamme". ' Vuonna 1870 ilmestyneessä kirjan saksankielisessä laitoksessa Thomsen (mts. 126) vielä lisäsi, että balttilainen kontaktikieli on ollut liettuan kanssa "auf ungefähr gleicher stufe". Näin määritelmään sisältyy jo neljä vanhinta balttilaista vaikutusta määrittelevää kriteeriä. Ensinnäkin se on eri kerrostumaa kuin lätin vaikutus liivin kieleen (viron latvialaisvaikutusta Thomsen ilmeisesti ei vielä tuntenut). Toiseksi se, että kontaktikieli on liettuan kanssa "samalla asteella" sulkee pois mahdollisuuden, että vaikutus olisi maantieteellisesti läheisemmästä mutta paljon innovatiivisemmasta lätin kielestä peräisin. Kolmanneksi vaikutus koskee koko itämerensuomea. Neljänneksi balttilainen vaikutus on varsin suuri, mitä Thomsen vielä korosti asettamalla sen samaan suurusluokkaan vanhan germaanisen vaikutuksen kanssa vanhan slaavilaisen vaikutuksen vähäisyyttä vastaan.

Itämerensuomalaisten ja balttilaisten kielten yhteisen sanaston olemassaolo havaittiin toki jo ennen Thomsenia, viimeistään 1700-luvulla. Henrik Gabriel Porthanin papereista on löydetty luettelo, jossa kolmeatoista suomen sanaa on verrattu äänteellisesti samannäköisiin liettuan sanoihin (Porthan 1873: 37-38). Ruotsalainen

\footnotetext{
${ }^{1}$ Tulkitsen Thomsenin tarkoittaneen termillä "den finske sprogstamme" itämerensuomalaisia kieliä.
} 
M. Johan Thunmann (1772: 8, 75-89) mainitsi yhteensä 110 itämerensuomalaisille ja balttilaisille kielille yhteistä sanaa, mutta tulkitsi ne väärin suomalaisten osuutena balttilaiskielten muodostumisessa. Ensimmäisen oikeansuuntaisen päätelmän tämän sanaston alkuperästä esitti Rasmus Rask (1818: 153): balttilaiset kielet kuuluvat indoeurooppalaiseen ja itämerensuomalaiset kielet suomalais-ugrilaiseen kielikuntaan, ja yhteiset sanat ovat lainaa, enimmäkseen edellisistä jälkimmäisiin. Hän jätti kuitenkin määrittelemättä, missä kielihistoriallisessa kontekstissa sanat olivat näitten kielten väliä kulkeneet. Niinpä Thomsen oli ensimmäinen, joka esitti pätevän määritelmän itämerensuomen vanhoille balttilaisille lainoille.

Kööpenhamina oli 1800-luvun jälkipuoliskolla yksi maailman lingvistiikan - tuohon aikaan ennen kaikkea historiallis-vertailevan indoeuropeistiikan - johtavia keskuksia, ja fennougristiikan kehitys oli indoeuropeistiikasta vuosikymmeniä jäljessä. Thomsenin aikalaiset käsittelivät itämerensuomalais-balttilaisia kontakteja heikommin metodein ja vääristä oletuksista lähtien. August Ahlqvist (1866: 101102) uskoi balttilaisperäisen sanaston kulkeutuneen suomeen joskus esihistorian myöhäisvaiheessa latvian, liivin ja viron kautta, Nikolai Anderson (1879: 103) taas näki siinä joko yhteisiä lainoja skyyttien kielestä tai todisteita suomalais-ugrilaisten ja indoeurooppalaisten kielten alkusukulaisuudesta. Mihkel Wesken (1890: 138-140) rakennelma perustui kirjoittajan itse hataralle pohjalle rekonstruoimille indoeurooppalaisille kantakielitasoille. Wilhelm Tomaschekin $(1883,1889)$ tutkimukset olivat varsin kestävällä pohjalla, mutta hän keskittyi niissä itäisempien suomalais-ugrilaisten kielten lainasanastoon. Sen sijaan József Budenz oli perehtynyt myös Thomsenin tutkimuksiin ja esitti etymologisessa sanakirjassansa (Budenz 1875: 382, 389) pari uuttakin muinaisbalttilaista etymologiaa. (Ks. tarkemmin Junttila 2005: 14-18.)

Otto Donner pyrki antamaan yleisesityksen suomen muinaisbalttilaisista lainoista. Donner (1884) luettelee sata varmana ja yhdeksän epävarmana pitämäänsä balttilaista etymologiaa, joista lähes puolet (49) on peräisin Ahlqvistilta. Runsas puolet Donnerin etymologioista osui oikeaan, samoin osa Donnerin niistä johtamista kieli-, asutus- ja kulttuurihistoriallisista päätelmistä, mutta kirjoituksen merkitys jäi aivan marginaaliseksi.

Miksi? Koska vuonna 1890 ilmestyi Thomsenin toinen fennougristiikan alan pääteos Beröringer mellem de finske og de baltiske (litauisk-lettiske) sprog, joka keskittyy itse asiaan eli itämerensuomalaisten kielten muinaisbalttilaisiin lainoihin. Thomsen hallitsi suvereenisti aikansa historiallis-vertailevan indoeurooppalaisten kielten tutkimuksen ja oli perehtynyt myös arkeologiaan. Beröringeriin Thomsenin onnistui vielä kerätä kaikki tuohon aikaan saatavilla ollut olennainen tieto itämerensuomesta, saamesta, mordvasta ja marista. Thomsen esitti itämerensuomesta 200 muinaisbalttilaista etymologiaa, joista 104:ää hän piti aivan varmoina. Näistä 200 etymologiasta oli Donnerin artikkelissa esiintynyt vain 67 , useimmat ovat Thomsenin omia. Thomsenin etymologiat muodostavat vielä 140 eli $48 \%$ kaikista Suomen sanojen alkuperän (SSA) mainitsemista 294 balttilaislainaoletuksesta. On otettava huomioon, että kaikki Thomsenin balttilaisperäisinä esittämät itämerensuomalaiset sanat eivät esiinny suomessa. SSA käsittelee yhteensä 182 Thomsenin tutkimaa sanaa, 
joista 140 oikeana tai mahdollisena pidettyä etymologiaa on peräti $77 \%$. Useimmat sittemmin kumotut Thomsenin etymologiat ovat olleet hänen kysymysmerkillä varustamiansa (SSA:ssa 42:sta 33), ja valtaosassa tapauksia sopiva lainaoriginaali löytyy muusta muinaisindoeurooppalaisesta kielimuodosta. Kaikki vuoteen 1936 mennessä esitetyt itämerensuomen muinaisbalttilaiset etymologiat tutkijoittain olen kirjannut kirjoituksen lopussa olevaan liitteeseen, josta hyvin nopeallakin vertailulla voi varmistua Thomsenin työn huomattavasta laajuudesta.

Thomsenin teos oli briljantti ja hänen nuorgrammatiikkaa edustava äännehistoriallinen metodinsa eksakti. Thomsenia voi hyvällä syyllä pitää suomen ja sen lähisukukielten kielihistorian perustajana. Jooseppi Julius Mikkolan (1927: 298) mukaan fennougristiikassa ei ollut kielihistoriaa ennen Thomsenia. Ainakin on varmaa, että nuorgrammatiikka tuli Suomeen Thomsenin ansiosta. Nuorgrammatiikan pioneerina meillä muistetaan nykyään ennen kaikkea Emil Nestor Setälä, mutta Setälän opettajista tärkein oli Thomsen.

Beröringerin ilmestyttyä itämerensuomalaisten kielten balttilaisista lainoista tuli saman tien suomalais-ugrilaisten kielten sanaston parhaiten tutkittu osa-alue. Aiheen aiemman tuntemattomuuden ja sen Thomsenilta saaman perinpohjaisen käsittelyn vuoksi teos ei kuitenkaan synnyttänyt juuri minkäänlaista keskustelua. Thomsenin ajatuksilla oli keskeinen osuus Setälän ja arkeologi Alfred Hackmanin edelleen muovaamaan maahanmuuttoteorian syntymisessä. Kielitieteen ja arkeologian näennäisen kompromissin tuloksena balttilaiskontaktien pääpiirteet, ajoitus, ympäristö, etno- ja kulttuurihistoriallinen konteksti sekä lainojen äänteellinen mukautuminen kohdekieleen olivat tutkijain valtavirran mielissä causa finita vielä vuosikymmeniä.

Thomsenin tulokset ovatkin vanhenneet lähinnä siellä, missä hänen lähdetietonsa ovat vanhenneet. Erityisesti tämä koskee paljon Thomsenia vanhemman, ainakin Porthaniin (1859: 46) asti jäljitettävän tutkimustradition mukaista käsitystä suomalaisten myöhäisestä maahanmuutosta, johon perustuu balttilaiskontaktien Thomsenilta saama ajoitus pääosin ajanlaskun alun tienoille ja sen jälkeisiin vuosisatoihin. Hackmanin jonkin verran aikaistettua maahanmuuton ajoitusta Setälän koulukunta loi samalta pohjalta suomen kantakielivaiheitten kronologian, joka kauan pysyi vallitsevana paradigmana, ja on vasta vähitellen väistynyt 1900-luvun kuluessa. Samalla on menettänyt kannatustansa myös Thomsenin käsitys kontaktialueen sijainnista sisämaassa jossakin Baltian itäpuolella.

Thomsenin ajoitukset ja paikannukset kohtasivat toki kritiikkiä jo huomattavasti aiemmin, ennen kaikkea arkeologien ja arkeologian avulla operoivien kielentutkijain taholta, mutta Setälän auktoriteetti vaikutti osana tutkimusperinnettä hyvin kauan, mikä lykkäsi ja pitkitti paradigmanvaihdosta. Vasta Tvärminnessä 1980 pidetyn symposiumin julkaisussa Suomen väestön esihistorialliset juuret (Gallén 1984) paradigmanvaihdos tulee seikkaperäisesti esiin ennen kaikkea Korhosen, Carpelanin, Sammallahden, Salon ja Jutikkalan artikkeleissa. Pitkään eli myös Thomsenin käyttämä termi liettualaiset lainat, joka on aiheuttanut paljon väärinkäsityksiä. Thomsen ei pitänyt muinaisbalttilaisten lainojen lähdekielenä liettuaa, hänen aikanaan ei vain käsite balttilainen ollut vielä vakiintunut käyttöön. 
Varhaisempi Thomsenin teoksen kritiikki kohdistui sen liian negatiiviseen arvioon vanhojen itämerensuomalaisten lainojen mahdollisuudesta balttilaisissa kielissä. Thomsenin pääajatukset ovat kuitenkin edelleen voimassa: itämerensuomalaisen kantakielen puhujat elivät hyvin läheisissä yhteyksissä balttilaisen kielimuodon puhujiin useamman vuosisadan ajan, mistä on tuloksena iso joukko lainasanoja itämerensuomalaisissa kielissä. Nämä lainat eivät ole yhdistettävissä mihinkään nykyiseen tai historialliseen balttilaiseen kielimuotoon, ja ne on erotettava eteläisten itämerensuomalaisten kielten myöhemmistä lättiläisistä lainoista. Lainat todistavat pitkäaikaisesta rinnakkaiselosta, koska joukossa on hyvin keskeistä sanastoa, jopa ruumiinosien nimiä. Tarkemman balttilaislainain ryhmittelyn merkityksen ja kulttuurihistoriallisen kontekstin suhteen on tehnyt vasta Seppo Suhonen (1984: 207-225). Pienehkö kerrostuma balttilaisia lainoja on myös mordvassa, josta osa sanoista on kulkeutunut mariin asti, mutta balttilaiskontakteja ei voi ajoittaa itämerensuomen ja mordvan yhteiseen kantakieleen. Beröringer esittää ensimmäisenä sittemmin pitkäksi ajaksi vakiintuneen lainasanakerrostumiemme suhteellisen kronologian: balttilaiskontaktit alkoivat ennen germaanisia, mutta jatkuivat pitkään näitten kanssa rinnan. Donner (1884: 260) piti "goottilaista" lainakerrostumaa balttilaista vanhempana ja Thomsen itsekin vielä kahta vuosikymmentä aiemmin (1869: 108) suunnilleen samanikäisenä.

\section{Suomalaistutkijat Thomsenin työn jatkajina}

Thomsenin luomaa kuvaa tarkensivat sittemmin uusilla etymologioilla ennen kaikkea suomalaiset tutkijat. Thomsenilta oppia saaneet Setälä ja Mikkola toivat heti Beröringerin ilmestyttyä nuorgrammaattisen metodin Suomeen, jossa kansallinen innostus loi oman kielen tutkimukselle loistavat kehitysmahdollisuudet. Vuosisadan vaihteessa säännöllisesti ilmestyä alkaneet Kotikielen Seuran Virittäjä (1897-) ja Setälän yhdessä muitten johtavien suomalaistutkijain kanssa julkaisema FinnischUgrische Forschungen (1901-) nousivat lainasanatutkimuksen pääareenoiksi Suomalais-Ugrilaisen Seuran julkaisujen ohella. Tämä merkitsi myös itämerensuomalais-balttilaisten kosketusten tutkimusten yhä voimakkaampaa keskittymistä Suomeen. Vielä 1880-luvulla suomalaiset olivat olleet oman kielikuntansa tutkimuksen kehityksestä jäljessä, mutta tilanne kääntyi pian, kun suomalaisten "omittua" lainasanatutkimuksen ja Thomsenin metodit suomalaisia julkaisuja vähemmän seuranneet ulkomaiset tutkijat jäivät tutkimuksen kärjestä. Seuraavaksi onkin syytä ottaa esiin alan tärkeimmät suomalaistutkijat.

Setälä opiskeli Thomsenin johdolla Kööpenhaminan yliopistossa Beröringerin kirjoittamisen aikaan (Mikkola 1927: 298). Setälä esitteli Thomsenin teosta useissa erikielisissä tieteellisissä julkaisuissa. Toisin kuin Thomsen, Setälä ei uskonut mahdollisuuksiin löytää enää montakaan uutta balttilaista etymologiaa. Itse hän esitti niitä vain muutaman, joista edelleen voimassa ovat kaarna ja metu sekä mytologinen kurko (Setälä 1894: 278; 1897; 1912: 194-197). Kansallinen mytologia olikin Setälän erityisen mielenkiinnon kohde: nimistä Ajattara, Kaleva ja kouko hän kirjoitti puolustaen niille esitettyä balttilaista etymologiaa (Setälä 1902: 161; 1907: 249-250; 1912: 
183-194). Viimeksi mainittua alun perin Matti Warosen etymologiaa pidetään edelleen mahdollisena. Niin ikään mytologissävyiselle etnonyymille vuojolainen Setälä (1932) esitti balttilaisen etymologian, jota nykyään ei pidetä perusteltuna.

Uudeksi huomion kohteeksi Setälä ja Heikki Paasonen nostivat arjalaisen ja kantaindoeurooppalaisen lainasanakerrostuman, joita Thomsen ei ollut juuri tutkinut. Monet Thomsenin balttilaisperäisinä pitämät sanat osoitettiin nyt näihin vanhempiin kerrostumiin kuuluviksi, useimmiten niihin sopivien vastineitten löydyttyä balttilaiskontaktien kannalta liian etäisistä sukukielistä. Paasonen tarkensi erityisesti kuvaa itämerensuomen, balttilaisten kielten ja mordvan keskinäisistä suhteista. Uusia muinaisbalttilaisia etymologioita Paasonen löysi vain vähän: näistä ovat jääneet elämään vuona ja jo Wesken (1890: 217) liettuaan yhdistämä liika (Paasonen 1909a: 89; 1917).

J. J. Mikkola väitteli tohtoriksi vuonna 1893 tutkimuksella Berührungen zwischen den westfinnischen und slavischen Sprachen (Mikkola 1894), jonka rakenne ja metodi noudattavat Beröringer-teoksen mallia. Ensimmäisenä suomalaisena tiedemiehenä Mikkola myös opiskeli Liettuassa vuosina 1893-1894 ja puhui sittemmin hyvin sekä liettuaa että latviaa. Nuorena tutkijana Mikkola täsmensi ja paranteli Thomsenin rakennelmaa suomen lainasanakerrostumista, mutta myöhemmin hän alkoi vierastaa lainaetymologiaa, kiisti Thomsenin johtopäätösten arvon ja pyrki osoittamaan indoeurooppalaisten naapurikielten osuuden suomen kielen kehityksessä vähäiseksi. Suunnanmuutos näkyy Mikkolan tutkimuksissa balttilaislainojen alalla: parin ensimmäisen vuosikymmenen aikana hän esitti uusia lainoja ja korjasi Thomsenin lainaoletuksia lähdekielen osalta. Mikkolan löytämiä varmoja tai mahdollisia muinaisbalttilaisia lainoja ovat hako, karsta ja kiiliäinen (Mikkola 1894: 15, 126-127; 1906: 78). Näitten lisäksi Mikkola esitti lukuisia epävarmoja etymologioita, joita nykyään ei enää pidetä pätevinä. Mikkola (1906) toisti Setälän kannan, että Thomsen on balttilaislainat "niin tarkoin koonnut ja tutkinut - - että ei niitä monta enää keksittäne lisää". Vanhoilla päivillään Mikkola yhtyi Thomsenin ja Setälän kriitikoitten rintamaan (vrt. alla s. 66-67).

Eemil Aukusti Tunkelo esitti vuonna 1899 balttilaislainojen ulottuvan Suomen paikannimistöön. Kysymys on Hämeestä ja Auhtosten kylän nimestä, joista jälkimmäiseen liittyy myös sana auhto 'hiekkainen, karu; pehmeä; haalistunut'. Tunkelolla Auhto(i)s- lt aukštotis 'ylämaalainen' ja Hämäis-, hämäläinen 1t žemaitis 'alamaalainen'. Wiklund kumosi pian (1900) Tunkelon auhto-etymologian saamesta löytämänsä vastineen tuella, asettamatta silti kyseenalaiseksi tämän Häme-etymologiaa. Häme vanhana heimonnimenä oli kansallistietoisuudelle tärkeä sana, johon useat tutkijat yhdistivät saamelaisten omakielisen etnonyymin sápmi (vrt. Genetz 1899, Setälä 1899). Balttilais-slaavilaisesta žem-vartalosta taas oli jo Porthan tahtonut johtaa nimen Suomi (Ojansuu 1899: 84). Tunkelo ei voinut suoralta kädeltä hylätä vanhaa Donnerin rinnastusta Häme vi hämm(e) 'kostea, märkä' unk semlyék 'soinen, vesiperäinen niitty’ (Tunkelo 1899: 106). Häme-sanan balttilaisuutta ei voi vieläkään pitää lopullisesti todistettuna. 
Vuonna 1928 Tunkelo kirjoitti karsinan ja luoman alkuperästä. Edellinen vastaa hänen mukaansa lt deminutiivimuotoa gardinys 'aitaus' (Tunkelo 1928: 285-287). Vastineiksi sopivia sanoja olisi myös germaanisella taholla, mutta Tunkelon kannan balttilaisen lainan eduksi ratkaisi se, ettei germaanisista lainoista ollut löydetty merkkejä *ti > si -muutoksesta. Tämä argumentti ei enää päde, mutta Tunkelon etymologiaa ei ole tietääkseni vielä kukaan julkisesti kyseenalaistanut.

1900-luvun alussa tieteellisen uransa aloittaneen fennougristisukupolven merkittävin etymologi oli Yrjö Henrik Toivonen. Uusia balttilaisia etymologioita Toivonen esitti kymmenen lyhyinä artikkeleina eri julkaisuissa vuosien varrella. Toivonen myös kumosi varhempia balttilaislainaetymologioita suomessa ja käsitteli (1928: 233) mordvalais-balttilaisia kontakteja hirssiä merkitsevien sanojen lt sora ja md suro pohjalta. Toivosen mukaan kysymyksessä on permiläisten kielten muotoihin yhdistettävä vanha arjalainen laina, joka on mordvasta kulkeutunut edelleen liettuaan. Sana on tarjonnut ainesta mielenkiintoiselle keskustelulle: sen latvialainen muoto ei ole säännöllisen äännekehityksen kautta yhdistettävissä liettualaiseen ja sen merkitys itämerensuomessa eroaa niin indoeurooppalaisten kuin suomalais-ugrilaistenkin kielten samankuuloisten sanojen merkityksestä.

Itämerensuomalais-balttilaisiin kontakteihin perehtyi myös suomen ja lähisukukielten tutkija Heikki Ojansuu, joka vuonna 1921 julkaisi laajan artikkelin Lisiä suomalais-balttilaisiin kosketuksiin. Ojansuu hämmästeli, kuinka Beröringer-teoksen jälkeen on kyetty esittämään vain vähän yli kymmenen uutta balttilaislainaa, kun "suomalais-germaanisia rinnastuksia on voitu - - osoittaa satamäärin". Ojansuu oli käyttänyt samoja sanakirjoja kuin Thomsen, ja "tulos on se, että olen joutunut tekemään muutamia kymmeniä uusia yhdistyksiä, enimmät kuitenkin verraten vähäpätöisiä". Kunnian "mahdollisesta onnistumisestansa" Ojansuu antoi ensi sijassa Thomsenille. Kuitenkin hän mainitsi itämerensuomalaisten kielten äänneasun tutkimuksen Thomsenin päivistä "suuresti edistyneen" ja rohkeni siksi arvioida uudestaan myös muutamia tämän etymologioita. (Ojansuu 1921: 3-4.) Ojansuun varmoina esittämiä uusia muinaisbalttilaisia etymologioita on 20 ja epävarmoja kahdeksan. Edelliset ovat puolustaneet paikkaansa suhteellisen hyvin, kun taas useimmat epävarmat ovat vanhentuneet. Ojansuu löysi itämerensuomalaisten kielten ja liettuan sanastosta myös pari merkitysvastaavuutta, jotka hän katsoi mahdollisiksi selittää balttilaisina käännöslainoina. Näitä ovat maitoastiaa merkitsevä murteellinen läntymys, joka olisi balttilaisen mallin mukaan johdettu vanhasta lehmuksen nimestä lännys, sekä mahlakuu huhtikuun nimenä (mts. 23-24). Myöhemmät tutkijat eivät kuitenkaan ole pitäneet balttilaisten mallien analogiaa tarpeellisena näitten sanojen synnyn selittämiseksi.

\section{Balttilaiskontaktien tutkimus Suomen ulkopuolella}

Eräät ruotsalaisetkin tutkijat tarttuivat itämerensuomalais-balttilaisiin kontakteihin. Evald Lidén kirjoitti vuonna 1897 (s. 61), että aisa on selvästi balttilaista alkuperää. Sanalle ei nimittäin ole vastineita nykybalttilaisissa kielissä, mutta Lidén rekonstruoi sanan balttilaisen asun muitten indoeurooppalaisten kielten perusteella. Tällaista 
epäsuoran evidenssin varassa etymologiointia ei vielä Thomsen käyttänyt, mutta se kävi sittemmin varsin yleiseksi suomen vanhojen lainakerrostumien identifioinnissa ja uusien etymologioitten kehittelyssä. Samalla metodilla Lidén (1911: 198-202) rekonstruoi sanalle aitta balttilaisen originaalin slaavilaisissa kielissä esiintyvien vastineitten pohjalta. Merkittävä ruotsalainen fennougristi Björn Collinder ei esittänyt uusia balttilaisetymologioita, mutta tutki niitten äänteellisiä ominaisuuksia useissa töissänsä, joihin en tämän lyhyen artikkelin rajoissa kuitenkaan voi puuttua.

Beröringerin ilmestymisen aikaan ei ollut vielä juuri tutkittu saamen kielen kehitystä ja asemaa suomalais-ugrilaisessa kielikunnassa. Thomsen jätti saamen vähälle huomiolle muuten tässä niin perusteellisessa työssä, koska ei kokenut kykenevänsä itse saamen ja itämerensuomen välisiä äännesuhteita selvittämään. Ongelmakenttää ryhtyi setvimään ruotsalainen Karl Bernhard Wiklund, joka esitti saamesta paralleeleja useille suomen balttilaisille ("liettualaisille") lainoille. Ensimmäinen saamen kielihistoriaa käsitellyt tutkimus oli Wiklundin vuonna 1896 ilmestynyt Entwurf einer urlappischen lautlehre I. Wiklundin (1896: 40-41) mukaan "suomalais-saamelaisten ja balttilais-suomalaisten kontaktien välillä ei voi olla pitkää aikaväliä, ja myös suomalaisen kielen siirtyminen saamelaisille on sijoitettava mainittuun aikaan. Muuten odottaisi edes muutamien äännelakien toteutuneen näitten vaikutusten välisenä aikana." Tuohon aikaan oli nimittäin vallalla käsitys, että saamelaiset olivat vaihtaneet oman alkuperäisen kielensä kantasuomeen. Wiklund (mts. 42-44) laati teokseensa myös luettelon kantasaamelaisena aikana suomen kautta lainautuneista balttilaisista sanoista. Luettelo on kuitenkin aivan mielivaltaisesti koostettu, useimmat rinnastukset eivät nimittäin läpäise Wiklundin omia äännekriteerejä. Mukana on Thomsenin rinnastusten lisäksi vain muutama paikkansa pitävä lainaetymologia sekaisin aivan nuorten suomalaislainojen kanssa. Wiklund kuitenkin tuli löytäneeksi myös yhden mahdollisen balttilaisen etymologian: suomen slaavilaisena lainana pidettyä lavaa vastaa saamessa luovvi, mutta äännesuhde viittaa varhaisempaan lainautumiseen, jolloin originaalina tulee kyseeseen lt lova (mts. 45-46).

Wiklundin äännehistoriallinen rakennelma ei ollut kovin onnistunut, koska se jätti täysin huomiotta itäisten suomalais-ugrilaisten kielten aineiston. Paljon uskottavamman rekonstruktion laati vielä samana vuonna Arvid Genetz, jonka tutkimukset jäivät kuitenkin vuosikymmeniksi vaille ansaitsemaansa huomiota. Genetz luetteli "liettualaiset" sanat jokaisen käsittelemänsä saamen vokaalin yhteydessä. Useimpia Genetzin rinnastuksia pidetään edelleen oikeina. Genetzin työn suurin puute balttilaisperäisten sanojen tutkimuksen kannalta on, että sanoista, joissa ensitavun vokaalina on sm $a$ ja saa $u o$, hän mainitsi vain hajaesimerkkejä. Suurin osa saamen vanhoista balttilaisperäisistä sanoista kuitenkin kuuluu tähän ryhmään. Kattava luettelo jäi puuttumaan.

Wiklundin artikkelissa Om de västfinska folkens urhem och deras flyttning därifrån (1916) muinaisbalttilaiset lainat saavat keskeisen aseman todisteina suomensukuisten kansojen etnogeneesistä. Wiklund kirjoitti Thomsenin käsityksen suomalaisten alkukodin sijainnista Viron ja Liivinmaan itäpuolella tulleen jo yleisesti hyväksytyksi, mutta hän ei itse täysin tue tätä käsitystä (mts. 166). Thomsenin teorian 
suomalaisten maahanmuutosta 700-800-luvuilla jKr. olivat jo monet kielitieteilijät ja arkeologit asettaneet kyseenalaiseksi: Wiklund viittaa Hackmaniin, joka oli siirtänyt maahanmuuttoa noin puoli vuosituhatta kauemmaksi menneisyyteen (mts. 165; Hackman 1905: 348; vrt. Eisen 1917: 11-12). Suomenruotsalainen germanisti Tor Evert Karsten ajoitti balttilais-itämerensuomalaiset kontaktit pronssikaudelle, tuskin paljon myöhemmiksi kuin $1000 \mathrm{eKr}$. (Karsten 1915: 201). Wiklund (mts. 168) asettui samoille linjoille ja olettaa kontaktien päättyneen viimeistään $600-500$ eKr. Thomsenkin korjasi pian ajoituksiansa, mutta vain paria vuosisataa aiemmiksi (Thomsen 1919: 250). Näin parannellut ajoitukset pysyivät vallitsevana totuutena yli puoli vuosisataa.

Virossa kansalliset tieteet pääsivät kehittymään hitaammin kuin Suomessa, olihan yliopisto Tartossa saksalais-venäläinen aina tsaarinvallan ajan loppuun saakka. Ensimmäisen omakielisen esityksen viron kielen esihistoriasta kirjoitti 1910-1911 Jaan Jõgever otsikolla Eesti muinasajast. Jõgeverin tieto lainakontakteista perustui kuitenkin Thomsenin 40 vuoden takaiseen Indflydelse-teokseen. Myös Villem Grünthal kirjoitti aiheesta varsin omintakeisesti, mutta esitti ensimmäisenä (1910: 280) heisipuun vanhana "liettualais-lättiläisenä" lainana, mitä voi edelleen pitää onnistuneena etymologiana, samoin kuin Jaan Lõon (1911: 86) löytämää balttilaisetymologiaa sanalle tiine. Julius Mägiste puolestaan (1923: 35-36; 1925: 88) löysi balttilaiset vastineet sanoille kutsua ja vinka 'häkä'. Oskar Loorits laati ansiokkaan artikkelin viron lättiläisistä lainasanoista (Loorits 1929), jossa hän esitti sanaa malo mahdollisena vanhana balttilaisena lainana sen laajan itämerensuomalaisen levikin vuoksi.

Aikansa ansioitunein baltologi, latvialainen Jānis Endzelīns kirjoitti vuonna 1912 kuurilaisista, Latvian ja Liettuan länsiosissa eläneestä kansasta, joka mainitaan useissa keskiaikaisissa lähteissä mutta joka sittemmin on sulautunut lätteihin ja liettualaisiin. Aiemmat tutkijat, mm. Thomsen, olivat pitäneet kuurilaisia itämerensuomalaisena kansana, lähinnä liiviläisinä. Endzelīns pyrki nyt paikannimitutkimuksen avulla osoittamaan kuurilaiset balteiksi. Kuurilaisten viron- ja liivinkielisen nimen - vi kuralane, li kurali - hän yhdisti lv kursi ja lt kuršas -nimiin: jos kyseessä on vanha balttilainen laina, on säännönmukainen äänteellinen kehitys ollut Kur- $<$ ksm *kurh- $<$ ba kurš(Endzelīns 1912: 72). Vuonna 1913 Endzelīns julkaisi artikkelin lätin kielen kuurilaisperäisestä sanastosta ja esitti siinä kuurilaisina lainoina myös niitä liivin kielen balttilaisperäisiä sanoja, jotka äänneasunsa puolesta edellyttävät selvästi latviaa vanhemmalla kannalla olevaa lainanantajakieltä. Endzelīnsin työtä kuurilaiskysymyksen selvittäjänä jatkoi sittemmin suomenmaalainen slavisti Valentin Kiparsky, joka ei kuitenkaan pitänyt mainittuja liivin sanoja todistetusti kuurilaisperäisinä.

Liettualaiset oli vertaileva indoeuropeistiikka 1800-luvulla kohottanut"Euroopan vanhimmaksi kansaksi”, mutta 1900-luvulle tultaessa tämä kansa oli vähän koulutettua ja enimmäkseen lukutaidotonta. Omien kansallisten tieteitten kehittämiseen liettualaisilla ei Venäjän sortopolitiikan vuoksi ollut mahdollisuuksia, ja liettuaksi julkaiseminenkin oli kiellettyä vuoteen 1904 asti. Pietarin yliopiston liettualaista Raamatun kielten professoria Kazimieras Jauniusta pidettiin suurena liettuan tuntijana, mutta kielentutkijana hän oli itseoppinut ja hänen käsityksensä kielten vaiheista olivat hyvin 
omintakeiset. Jaunius ei itse julkaissut juuri mitään, joten Pietarin yliopiston professori E. Volter sekä akateemikot P. Fortunatov ja A. Šahmatov järjestivät hänelle sihteeriksi nuoren Kazimieras Būgan, toivoen tämän saattavan painovalmiiksi Jauniuksen tiedot liettuan kieliopista ja murteista. Būga oli vuonna 1903 työhön ryhtyessänsä opiskellut vain pappisseminaarissa, mutta oli osoittanut jo varhain kiinnostusta kieliin, julkaisipa tuona vuonna pienen artikkelin itämerensuomalaisten kielten liettualaisista sanoistakin. Būga kertoo lumoutuneensa Jauniuksen kielihistoriallisista teorioista ja kirjoittaneensa niitä ylös kuusi paksua vihkoa. Näistä ensimmäiset neljä hän julkaisi vuonna 1908 Jauniuksen kuoleman jälkeen kirjana Aistiški studijai I. (Zinkevičius \& Kabelka 1958: 17-26; Būga 1924: III-V.)

Aistiški studijai käsittelee "aistilaista kielikuntaa" ja sen menneisyyttä Jauniuksen mielestä sana "balttilainen" voi viitata vain Itämeren alueeseen ja kansoihin kokonaisuutena (Būga 1908: 1), joten hän käytti Tacituksen Itämeren etelärannalle sijoittamaa heimonnimeä. Būga kirjoitti, että aistit asuttivat aikoinaan koko Baltiaa, myös Viroa (mts. 7). Kaikissa mahdollisissa kielikontakteissa aistit esitetään aina lainanantajaosapuolena. Aistien etevyyttä merenkulkijoina todistavat teoksessa useille naapureille muka lainautuneet termit, $\mathrm{mm}$. sm airo, antura, laiva, laide ja purje (mts. 8-9). Thomsenin käynnistämän keskustelun ja sitä seuranneen tutkimuksen kannalta arvioituna Aistiški studijai oli auttamattoman vanhentunut jo ilmestyessänsä. Aistiški studijaissa suomen aistilaisten lainojen ainoana määrityskriteerinä on äänteellinen yhteensopivuus Jauniuksen teorioihin, ja niinpä sen sivuilta löytyy niin latvialaisia, esilatvialaisia, liettualaisia, esiliettualaisia ja muinaispreussilaisia kuin peräti "kantaaistilaisiakin" lainoja. Aistiški studijain 227 "aistilaisesta" lainasta 138 on aiemmilla tutkijoilla esiintymättömiä etymologioita. Mainituista sanoista SSA käsittelee 118 pitäen balttilaisperäisinä varmasti vain kolmea (ketara, puusniekka, reuna) ja mahdollisesti kolmea (hirsi, leuka, luoma). Lisäksi seitsemää Būgan sanaa (haastaa, järvi, koipi, luode, ranta, suola ja vilkaista) on Kari Liukkonen (1999) uudelleen esittänyt balttilaisina lainoina.

Būga opiskeli Aistiški studijain ilmestymisen aikaan jo kielitiedettä Pietarin yliopistossa, ja käsitti pian kirjan pääkohdat virheellisiksi. Būgasta tuli sittemmin Liettuan johtava kielentutkija. Hän ansioitui erityisesti liettuan sanaston tutkimuksen alalla ennen varhaista kuolemaansa vuonna 1924. Būga oli kirjeenvaihdossa usean suomalaistutkijan kanssa ja hyödynsi ahkerasti fennougristien tuloksia omissa tutkimuksissansa, esimerkiksi selvittäessänsä balttilaisten kielten vanhoja germaanisia lainoja (Būga 1921: 12-28). Itämerensuomalaisten kielten vanhoja balttilaislainoja hän sivusi useammassa tutkimuksessa, mutta ei itse enää julkaissut uusia etymologioita ennen kuin päätyössänsä, suuressa liettuan kielen sanakirjassa. Sanakirjasta ehti ennen Būgan kuolemaa ilmestyä vain osa $a$-alkuisia sanoja ja kesken jäänyt pitkä johdanto, jossa hän käsittelee balttilaisten kielten äänteellisiä piirteitä ja sanastoa. Erityisesti huomattava on Endzelīnsin työtä jatkava artikkeli kuurin kielestä. Būga antoi ajoituksen Endzelīnsin kura- < *kurša -etymologialle: sanan on oltava vanhempi kuin itämerensuomen vanhojen slaavilaisten lainojen, jossa $* \check{s}>h$-muutosta ei ole tapahtunut, eli viimeistään 600-luvulta. Būga pyrki osoittamaan kuurilaisperäisiksi oikeas- 
taan kaikki Thomsenin löytämät vain liivissä esiintyvät vanhat balttilaiset lainat. (Būga 1924: XCIII-CXXXIII). Būga ei tästä kuitenkaan jatkanut päättelyänsä koko itämerensuomen vanhan balttilaislainakerrostuman alkuperäkielen nimeämiseen; sen teki vasta Eino Nieminen.

\section{Thomsenin paradigman kritiikki Suomessa}

Suomessa vasta Setälän koulukuntaa seurannut tutkijasukupolvi ryhtyi varsinaisesti kritisoimaan thomsenilaista tutkimuslinjaa. Karsten nosti balttilaisten lainojen äänteelliset piirteet puheenaiheeksi osana suomalaisten esihistoriaan liittyvää kielitieteellis-arkeologista kiistaa, josta ei puuttunut tieteenulkoisia, poliittisiakaan motiiveja. Karsten tahtoi osoittaa suomesta esigermaanisia lainoja, jotka todistaisivat hyvin vanhoista suomalaisten ja skandinaavien edeltäjien välisistä kontakteista Suomen alueella. Karstenin mukaan sanat, joissa kantagermaanin sanansisäistä soinnitonta klusiilia vastaa suomen yksittäisklusiili, on omaksuttu ennen indoeurooppalaisen kantakielen soinnillisten klusiilien muutosta kantagermaanin soinnittomiksi klusiileiksi. Tällöin Karstenin oli kuitenkin selitettävä, miksi balttilaiset soinnittomat klusiilit edustuvat suomessa germaanisista poiketen useimmin lyhyinä. Seurasi vuosikymmeniä kestänyt väittely, jossa suomenruotsalaisten suoraa polveutumista Suomessa eläneestä muinaisgermaanisesta väestöstä puoltaneet Karsten ja Wiklund pyrkivät esittämään balttilaisten ja itämerensuomalaisten kielten $k$-, $t$ - ja $p$-äänteet olennaisesti germaanisten kielten vastaavista äänteistä eroaviksi kaikin mahdollisin argumentein. Vastakkaisella kannalla ollut Collinder taas pyrki kumoamaan kaikki Karstenin teesit ja esitti lukuisia esimerkkejä suomen astevaihtelusarjojen sekoittumisesta niin lainoissa kuin omaperäisessäkin sanastossa todistaaksensa, ettei klusiilien edustuksen perusteella voi tehdä päätelmiä lainasanojen iästä. (Karsten 1922, 1926-1927; Collinder 1924, 1932). Karsten myös esitti germaanisina useita sanoja, joitten alkuperää on pidetty joko germaanisena tai balttilaisena (kaleva, kupo, laita, olut, ruis), mutta myös muutamia vallinneen käsityksen mukaisesti varmoja vanhoja balttilaisia lainoja. Tärkeitä mytologiaan liittyviä nimiä perkele ja kouko Karsten piti kanta- tai esigermaanisina lainoina sekä itämerensuomalaissa että balttilaisissa kielissä (Karsten 1915: 20-24, 114).

Mikkola kritikoi ankarasti thomsenilaista lainaetymologiointia arvostellessansa mm. sanan kantele balttilaista etymologiaa: Mikkola selittää sen kanta-sanan johdokseksi (Mikkola 1925, 1932). Esitelmöidessänsä vanhimmista itämerensuomalaisten ja balttilaisten kielten välisistä yhteyksistä Latvian yliopistossa vuonna 1930 Mikkola kyseenalaisti useita varmoina pidettyjä balttilaisia etymologioita. Mikkola esitti perkeleen omaperäisenä johdoksena ja yhdisti metsän samankuuloisiin etäsukukielten sanoihin. Kypärä, kataja, maja, purje ja laiva ovat Mikkolan mukaan lainautuneet itämerensuomesta balttilaisiin kieliin eivätkä päinvastoin, kuten Thomsen oli olettanut. Mikkola osoitti tueksensa kypärän ja majan saamenkieliset vastineet, katajassa esiintyvän suomalaisen johdinaineksen (vrt. pihlaja, petäjä) sekä suomen ja viron rikkaan laiva- ja veneterminologian. Kypärää lukuun ottamatta nykytutkimus 
onkin näitten sanojen suhteen Mikkolan kannalla. Mutta Mikkolan mukaan jo sanan saamenkielisen vastineen olemassaolo todistaa sen balttilaista alkuperää vastaan, joten hän taipui pitämään halla-, heinä- ja hihna-sanoja omaperäisinä. Myös sillan ja morsiamen balttilaisista etymologioista olisi Mikkolan mielestä luovuttava, koska ksm *ti > si -muutos koskee vain tapauksia, joissa *ti palautuu asuun *te tai *ta. Lainaetymologian vierastaminen liittyi Mikkolan ajatukseen kantasanojen alkusynnystä kielen kaikissa kehitysvaiheissa, ja samanlainen suunnanmuutos näkyy Mikkolan vuonna 1938 julkaisemassa väitöskirjan uudessa laitoksessa. Suomen balttilaisperäisen sanaston Mikkola selitti latvian vaikutuksella. (Mikkola 1930: 440-444.)

Mikkolan latviankielisen esitelmän arvosteli Endzelīns kiinnittäen huomionsa tämän perusteluitta esittämään käsitykseen latviasta vanhojen balttilaislainojen lähdekielenä. Koska mitkään kielelliset seikat eivät viittaa lainojen latvialaiseen alkuperään, Endzelīns päätteli Mikkolan tulleen johtopäätökseensä puhtaasti maantieteellisin perustein. Hän huomautti, että itämerensuomalaiset ovat voineet elää muittenkin balttilaisten heimojen naapureina. Endzelīns pyrki itse jäljittämään lainojen lähdekieltä äänteellisin kriteerein. Hän joutui kuitenkin turvautumaan varsin suppeaan aineistoon, koska ei uskaltanut käyttää Mikkolan hylkäämiä etymologioita - painettujen lähteitten lisäksi hän viittasi Mikkolan kirjeeseen, jossa tämä ilmoittaa epäilevänsä sanojen lohi, oinas, toe ja taivas balttilaista alkuperää. Näin Endzelīns joutui toteamaan, ettei itämerensuomessa ole ainuttakaan varmaa esimerkkiä, jossa $o$ vastaisi ba $a$ :ta, eikä yhtään varmaa kantabaltin $e i$-diftongin edustusta, ja tuli siihen negatiiviseen tulokseen, ettei itämerensuomen vanhojen balttilaisten lainojen lähdekieltä voi päätellä äänteellisin perustein. Tämän Endzelīnsin tuloksen otti Jalo Kalima sittemmin kakistelematta oppikirjaansa, vaikkei hyväksynyt sen premisseinä olleita Mikkolan käsityksiä. (Endzelīns 1933; Kalima 1936: 188.)

\section{Suomalaisten slavistien sukupolvi: Kalima ja Nieminen}

Jalo Kalima oli itämerensuomalaisten ja slaavilaisten kielten tutkijana J. J. Mikkolan työn jatkaja. Kalima toimi Helsingin yliopistossa itämerensuomalaisen kielentutkimuksen dosenttina vuodesta 1924 alkaen ja slaavilaisen kielentutkimuksen professorina vuosina 1935-1953. Kesällä 1927 Kalima matkusti Liettuaan aikeenaan valmistella oppikirja vanhoista balttilais-suomalaisista kielellisistä kosketuksista. Oppikirjan valmistelu viipyi, mutta Kalima julkaisi eräitä etymologisia havaintojansa lyhyehköissä artikkeleissa. Sanoille pahla 'keppi' ja orsi Kalima (1928: 102-103; 1933a) löysi balttilaisen originaalin. Hän muistutti näitten lisäksi suomen seivästä tai riukua merkitsevistä sanoista balttilaisperäisiä olevan myös arta, malka, seiväs sekä vaaja. Kalima ehdotti, että virsi voisi olla lainautunut balttilaisesta sanaa merkitsevästä sanasta ja että saparon voisi yhdistää lt sanaan stabaras 'kuiva oksa' esimerkkinä ieur kielten $s t$-alkuisten sanojen lainautumisesta itämerensuomeen $s$-alkuisina (Kalima 1933a; 1933b: 135). Kalima myös löysi eräille aiemmille balttilainaoletuksille paremman alkuperänselityksen, mutta kumosi Mikkolan Thomsenia kohtaan osoittaman kri- 
tiikin. Kalima kiinnitti huomiota Mikkolan mainitsemiin samankaltaisuuksiin balttilaisten ja itämerensuomalaisten kielten syntaksissa ja sanasemantiikassa sekä otti ensi kertaa esille yhteiset piirteet objektin sijanvalinnassa ja genetiivi + agenttipartisiippi -rakenteessa (Kalima 1934).

Kalima julkaisi vuonna 1936 teoksen Itämerensuomalaisten kielten balttilaiset lainasanat, joka nimestänsä huolimatta käsittelee vain muinaisbalttilaisia kontakteja. Kalima antoi kirjassa myös lyhyen kuvauksen balttilaisista kielistä ja niitten asemasta indoeurooppalaisessa kielikunnassa. Kyseessä on ensimmäinen suomenkielinen esitys aiheesta, mutta sen arvoa vähentävät lukuisat asiavirheet. Arvostelijan mukaan kirjasta löytyykin "kolmatta sataa intonaatio-, merkitys-, lähdeviittaus- ym. virhettä" (Nieminen 1941: 134). Kalima esitti oppikirjassansa yhteensä 230 balttilaista etymologiaa: 127 varmoina, 77 epävarmoina ja 26 epätodennäköisinä tai hyvin epävarmoina. Etymologioita on siis 30 enemmän kuin Thomsenilla. Teoksessa ensi kertaa esiintyviä balttilaisia etymologioita on 29 , joista vain viisi Kalima esittää varmoina, lopuista 18 kysymysmerkillä varustettuina ja kuusi hajahuomioina äänteellisistä yhtäläisyyksistä. Näistä SSA käsittelee 24 sanaa pitäen vain kolmea varmana ja kahdeksaa epävarmana. Kalima piti useita aiempia balttilaisia etymologioita väärinä, sellaisiakin, joitten kannalla nykytutkimus taas on. Siihen nähden, mitä Kalima oppikirjansa esipuheessa lupaa epävarmojenkin lainaoletusten huomioimisesta, on outoa, että hän on koko teoksesta jättänyt pois Thomsenin kysymysmerkillä varustamista 99 etymologiasta 40 . Vain noin puolelle näistä sanoista oli esitetty varteenotettavia vaihtoehtoisia alkuperänselityksiä, eikä näitäkään voi kaikkia pitää Thomsenin balttilaista etymologiaa parempina. Thomsenin jälkeisten tutkijoitten etymologioista Kalima on jättänyt käsittelemättä vielä suuremman osan, yhteensä 49. Näistä eräät ovat myöhempien tutkijoitten kumoamia, kun taas toiset eivät olleet herättäneet vastaargumentteja. Monet ilmeisesti ovat jääneet Kalimalle tuntemattomiksi, toiset hänen on täytynyt tietoisesti karsia pois, onpa joukossa yksi hänen omansakin.

Kalima (1936: 189) korjasi Thomsenin käsitystä, että liettuassa ei ole itämerensuomalaisia lainoja: "Näyttää siltä, että Thomsenilla on ollut taipumus pitää balttilaisperäisinä sellaisiakin sanoja, joissa päinvastainen lainaussuunta tulee hyvin kysymykseen. On pätevästi osoitettu, että liettuassakin tavataan eräitä itämerensuomalaisia sanoja." Vanhojen balttilaislainojen lähdekielestä Kalima (mts. 188) kirjoitti: "Endzelin on tullut siihen negatiiviseen tulokseen, ettei ole määrättävissä, mistä balttilaisesta kielimuodosta - - sanat ovat kotoisin. Tämä kanta tuntuu täysin perustellulta." Endzelīnsin arvio kuitenkin perustui vain siihen suppeaan joukkoon sanoja, jonka balttilaista alkuperää Mikkola ei ollut halunnut asettaa kyseenalaiseksi.

Kaliman ajoitus balttilaiskontakteille oli samoilla linjoilla kuin Thomsenin uudempi arvio (Thomsen 1919: 250), joka korjasi Beröringerissä esitettyjä lukuja pari kolme vuosisataa varhaisemmiksi mutta erosi huimasti Karstenin ja Wiklundin paljon kauemmas menneisyyteen ulottuvista arvioista. Myöskään Kaliman (mts. 195) näkemys balttilaisten kontaktien maantieteellisestä paikannuksesta ei eronnut Thomsenin esittämästä: "Itämerensuomalainen heimo on ajanlaskumme alussa asunut Suomenlahden eteläpuolella, itään tai koilliseen balttilaisista heimoista - - balttilaiset kansat ylisen 
Dneprin tienoilla ovat ulottuneet niin kauas itään, että niiden muodostama kiila on estänyt slaaveja tunkeutumasta itämerensuomalaisen heimon naapuruuteen.”

Kaliman teoksen arvosteli aikansa suomalaistutkijoista parhaiten balttilaisiin kieliin perehtynyt Eino Nieminen. Nieminen oli paria vuotta aiemmin Kaliman pääkilpailija Helsingin yliopiston slaavilaisen filologian professuuria täytettäessä. Tiukka kilpailuasetelma jätti kahden miehen välille elinikäisen riidan. Virittäjän sivuilla käytiin balttilaislainoista keskustelua, jossa itse aihe oli unohtua molemminpuolisten nokkelien loukkausten ja ilkeitten sivallusten alle. Keskustelu balttilaiskontakteista kuitenkin samalla siirtyi fennougristeilta slavistien välille.

Eino Niemisen ensimmäinen oma julkaisu balttilais-itämerensuomalaisten kontaktien alalla oli pitkä artikkeli Der stammauslaut der ins urfinnische entlehnten baltischen ā-feminina und die herkunftsfrage vuodelta 1934. Nieminen tutki ieur $\bar{a}$-vartaloisten feminiinien kahtalaista edustusta, johon syyksi hän ei hyväksynyt Thomsenin selitystä abstrahoidusta nominivartalosta lainautumisesta, koska balttilaisesta kielestä sanoja omaksuneet osasivat varmasti tätä kieltä erinomaisesti (Nieminen 1934: 5-6). Nieminen pyrki todistamaan, että itämerensuomen sananlopun kahtalaisuuden riittää selittämään lainanantajakielen ensitavun vokaalin pituus. Kun kaksitavuisen sanan alkutavussa on ollut pitkä vokaali, diftongi tai lyhyen vokaalin ja nasaalin/likvidan yhtymä, edustuu jälkitavun ieur *ā:n jatkaja ims $A$ :na; kun taas alkutavussa on ollut vain lyhyt vokaali, edustuu sama vokaali $o$ :na. Niemisellä sanat kupo, puuro, rako jne. palautuvat ba muotoihin *gubō, *putrō, *spragō jne., sanat ansa, halla, terva jne. taas muotoihin *ansa, *šalna, *derva jne. Pääte *-ō edustaa

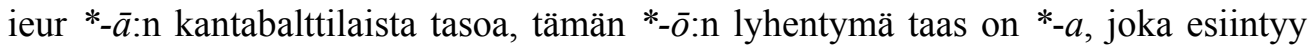
liettuassa kaikissa alkuperäisissä sananloppuisissa asemissa. Nieminen oletti, että lainanantajakielessä on nimenomaan painoton $*_{\bar{o}}$ sananloppuisessa asemassa lyhennyt *a:ksi, ja ennen sitä on tässä kielessä paino siirtynyt pitkältä laskevalta (akuutilta) jälkitavulta pitkälle ensitavulle. (Mts. 38-48.)

Nieminen pyrki löytämään vanhojen balttilaislainojen lähdekielen rekonstruoimiensa vokaalinkehitysten perusteella. Muinaispreussissa jälkitavun $* \bar{o}$ oli pitkä vielä keskiaikaisissa teksteissä. Liettua ei sovi lainanantajatahoksi, koska sananloppuinen

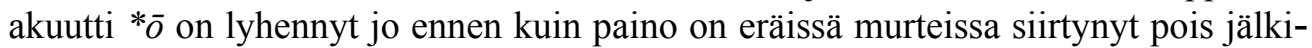
tavuilta. Sen sijaan mikään ei estä olettamasta, että jossakin innovatiivisemman latvian kielen esiasteessa olisivat olleet vallalla kuvatunlaiset äännesuhteet $\bar{a}$-vartaloisten nominien kesken. Nieminen kiinnitti nyt huomionsa etnonyymeihin. Ainoa hänen mukaansa kantasuomeen palautuva balttilaisen väestön nimitys on Endzelīnsin esittämä vi kuralane, li kurali 'kuurilainen'. Endzelīns ja Būga olivat osoittaneet kuurit balttilaiseksi heimoksi, joka oli tullut historiallisille asuinseuduillensa kaakosta asuttuansa Vilnan alueella kantasuomalaisten naapuruudessa vielä 500-luvulla $\mathrm{jKr}$. Tätä edeltävältä ajalta ovat peräisin paitsi itämerensuomalaisten kielten vanhimmat balttilaiset lainasanat, myös latvian murteissa esiintyvä virolaisia ja liiviläisiä merkitsevä sāms, jota Nieminen piti kuurilaisten välityksellä Suomi-nimestä lainautuneena: kuurilaisilla nimi olisi merkinnyt vielä itämerensuomalaisen kielen puhujaa yleensä. Näin vanhimmatkin balttilaiskontaktit voitaisiin yhdistää kuurilaisiin. (Mts. 48-64.) 


\section{Balttilaiskontaktien tutkimuksen vaikutukset lähialoille}

Etymologisesta kirjallisuudesta voi päätellä, että missään muualla Thomsenia ei luettu yhtä paljon kuin Suomessa tai hänen merkitystänsä käsitetty yhtä käänteentekeväksi. Niinpä esimerkiksi Viron saksalaisen Johannes Neuhausin vuonna 1908 kirjoittamassa suomen oppikirjassa kaikki etymologiat ovat vanhoja. Skandinavistiikan julkaisuissa Thomsenin todennäköisimmin balttilaisina pitämät napa ja terva toistuivat suomen vanhoina germaanisina lainoina (Kock 1903: 236; Noreen 1892: 57; 1903: 71; 1923: 85; Streitberg 1896: 45). Hugo Pipping (1905-1907: CXIV) esitti meri-sanan lainana muinaisgotlannista. K. F. Johansson (1900: 360) mainitsi peikon balttilaisena lainana. Etymologiaa ei ole Thomsenilla, eikä se täytä Thomsenin määrittelemiä äänteellisiä kriteereitä, mutta löytyy Diefenbachin (1851) puoli vuosisataa aiemmin ilmestyneestä sanakirjasta. Thomsenin epävarmana esittämä mutta suomalaistutkijain pian kuoppaama balttilainen etymologia sanalle lattea puolestaan jatkoi elämäänsä vielä Fraenkelin liettuan etymologisessa sanakirjassa vuosilta 1955-1965. Olisikin mielenkiintoinen tutkimushistoriallinen aihe selvitellä, miten suomen sanoja on käsitelty eri kielten etymologisessa tutkimuksessa ja kuinka nopeasti tai hitaasti meikäläisen tutkimuksen tulokset ovat saavuttaneet jalansijaa esimerkiksi ulkomaisissa etymologisissa sanakirjoissa.

Myös suomalais-ugrilaisten kansojen esihistorian alalla kansainvälinen tutkimus jäi selvästi jälkeen suomalaisesta, lukuun ottamatta Ruotsia, jossa vaikuttivat Wiklund, Lidén ja Collinder. Venäjäläinen Ivan Smirnov pyrki hyödyntämään kielitieteen tutkimustuloksia teossarjassansa Vostotšnyja finny. Istoriko-etnografitšeskija otšerki. Smirnov ei kuitenkaan pystynyt päättämään, tukeutuako lainakontaktien osalta Donneriin vai Thomseniin, lainasi molempia ja päätyi ristiriitaisiin tuloksiin. Brittiläinen arkeologi John Abercromby esitti hyviä huomioita balttilaiskontaktien merkityksestä kantasuomalaisille mutta teki muutamia varsin rohkeita päätelmiä lainasanojen perusteella. Abercrombyn mukaan kantasuomalaisten elämäntavassa saivat maanviljelys ja karjankasvatus balttilaisten vaikutuksesta keskeisemmän roolin, ja he alkoivat nähdä asioita, joita eivät ennen olleet pitäneet tärkeinä: apiloita, katajia, luhtaniittyjä jne. Jopa aurinko sai vasta tässä vaiheessa nimensä, samoin sellaiset viljelijälle merkittävät ilmiöt kuin halla, härmä ja routa. Balttien vaikutuksesta verisukulaisuuden merkitys kasvoi, ja vasta tällöin alettiin pitää sisaren, tyttären ja morsiamen eroa tärkeänä! (Abercromby 1898: 243-247.) Puolalaisen uskontotieteilijän Aleksander Brücknerin mukaan "liettualaiset" joutuivat kosketuksiin "suomalaisten" kanssa erottuansa slaaveista ja laajentaessansa aluettaan luoteen suuntaan (Brückner 1904: 8). Seurasi suorastaan "liettualais-suomalainen kausi". Sekoittuminen suomalaisiin mahdollisesti aiheutti liettualaisen kulttuurin vajoamisen takaisin metsästys-, keräily- ja šamanismiasteelle (mts. 13)! Aleksandr Šahmatov (1911) taas maalasi erikoisen kuvan Baltian eteläpuolella kelttien ja slaavien naapureina eläneistä itämerensuomalaisista. Todisteina ovat muka monet kelttiläiset ja kantaslaavilaiset lainasanat. Šahmatov luopui kelttiläisteoriastansa pian (Joki 1973: 128), kun Būga sekä aikakauden johtava slavisti Max Vasmer kumosivat sen väitteet. Huomionarvoista 
Vasmerin kritiikissä on, että hän kumosi eräitä Šahmatovin etymologioita auktoriteettinaan Būgan Aistiški studijai!

Thomsenin tutkimustulokset herättivät myös kansanrunoudentutkijat pohtimaan itämerensuomalais-balttilaisia yhteyksiä. Lainan käsitteen toi kielitieteestä suomalaiseen kansanrunoudentutkimukseen Julius Krohn. Alan tärkein tienraivaaja oli Helsingin yliopiston kansanrunouden dosentti, sittemmin professori A. R. Niemi, joka matkusteli vuosina 1908-1911 Liettuassa keräämässä lauluja, runoja, loitsuja ja taikoja. Niemi pyrki vertaamaan suomalaista ja virolaista aineistoa liettualaiseen ja löysi niin lauluista kuin niitten aiheista ja esitystavastakin suoranaisia balttilaisia lainoja, jotka hän päätteli samaa tietä tulleiksi kuin vanha balttilainen lainasanakerrostuma (Niemi 1912). Kaikki tutkijat eivät kannattaneet ajatusta kansanrunouden vanhoista balttilaisista lainoista: esimerkiksi Villem Grünthalin mielestä Niemen kysymyksenasettelu ei ollut kansanrunouden pysymättömän ja muuttuvaisen luonteen takia lainkaan mielekäs (Eisen 1910).

Tutkimushistorian esitys ei ole ajantasainen, ellei tutkimusta voida alusta asti tarkastella myös tämän päivän tutkimuksen näkökulmasta. Tähän minulla ei pro gradu -tutkielmani puitteissa vielä ollut mahdollisuutta. Ajantasaisen katsauksen toivon voivani esittää lähitulevaisuudessa, kun olen ennättänyt käydä läpi aiheesta myös vuoden 1936 jälkeen ilmestyneen kirjallisuuden.

\section{Lähteet}

Abercromby, John 1898: The Pre- and Proto-historic Finns both Eastern and Western with The Magic Songs of The West Finns. Vol. 1. London: David Nutt in the Strand.

Ahlqvist, August 1866: Om Finska språkets kulturord. Ett linguistiskt bidrag till Finnarnes äldsta kulturhistoria. - Suomi II: 6: 67-114. Helsinki: Suomalaisen Kirjallisuuden Seura.

Anderson, Nikolai 1879: Studien zur Vergleichung der ugrofinnischen und indogermanischen Sprachen. Dorpat.

Anderson, Nikolai 1893: Wandlungen der anlautenden dentalen Spirans im Ostjakischen. Ein Beitrag zur ugrofinnischen Lautlehre. Der Akademie vorgelegt am 18. April 1889. Mémoires de l'Académie Imperiale des Sciences de St-Pétersbourg, VIIe Série. Tome XL, No 2 et dernier. St-Pétersbourg.

Anderson, Nikolai 1896 = Андерсонъ, Н. И.: Этимологія названій kantele, kankles и т. д. - [Esitelmän tiivistelmä teoksessa] Труды десятаго археологическаго съпзда в Ригъ. Том II. Рига.

Brückner, Aleksander 1904: Starożytna Litwa. Ludi i Bogi. Szkice historyczne i mitologiczne. Warszawa: Nakłada Księgarni Naukowej.

Budenz, József 1873: Magyar-ugor összehasonlitó szótár. I füzet. Budapest: Magyar Tudományos Akadémia.

Budenz, József 1875: Magyar-ugor összehasonlitó szótár. II füzet. Budapest: Magyar Tudományos Akadémia.

Būga, Kazimieras 1908: Aistiški studijai. Tyrinèjimai lygintijo prūsu, latvju ir liètuvju kalbómoksljo srityjẹ: I-oji dalis. Peterburgas: Imperatoriškosjos Mokslų Akademijos Spaustuve. 
Būga, Kazimieras 1921: Kalba ir senovè. - Svietimo Darbas 5-6: 12-28, 141-152.

Būga, Kazimieras 1924: Lietuviu kalbos žodynas. I sąsiuvinis. Kaunas: Valstybès spaustuvè. Collinder, Björn 1924: Några problematiska germanska lånord i finskan. - Festskrift tillägnad Hugo Pipping på hans sextioårsdag den 5 november 1924. Skrifter utgivna av Svenska Litteratursällskapet i Finland CLXXV. Helsingfors: Svenska Litteratursällskapet i Finland. 77-89.

Collinder, Björn 1932: Die urgermanischen lehnwörter im finnischen. Skrifter utgivna av K. Humanistiska Vetenskap-Samfundet i Uppsala. 28:1. Uppsala - Leipzig: K. Humanistiska Vetenskap-Samfundet i Uppsala.

Diefenbach, Lorenz 1851: Vergleichendes Wörterbuch der Gothischen Sprache. Lexicon comparativum linguarum Indogermanicarum. Frankfurt am Mayn.

Donner, Otto 1884: Über den Einfluss des Litauischen auf die finnischen Sprachen. - Techmers Internationale Zeitschrift für allgemeine Sprachwissenschaft I: 257-271.

Eisen, Matthias Johann 1910: Leedu mõju Eesti rahvaluules. - Eesti Kirjandus V: 456-460.

Eisen, Matthias Johann 1917: Meie esivanemate algkodu ja siia kolimine prof. K. B. Wiklundi valgustusel. - Eesti Kirjandus XII: 11-20.

Endzelīns, Jānis 1912 = Endzelin, J.: Über die nationalität und sprache der kuren. FinnischUgrische Forschungen 12: 59-72.

Endzelīns, Jānis 1913 = Endzelin, J.: Zu den kurischen Bestandteilen des Lettischen. - Indogermanische Forschungen XXXIII: 96-104.

Endzelīns, Jānis 1933 = Endzelin, J.: Zur Herkunft der baltischen Lehnwörter des Finnischen. - Liber Semisaecularis Societatis Fenno-Ugricae. Suomalais-Ugrilaisen Seuran toimituksia LXVII. Helsinki: Suomalais-Ugrilainen Seura. 76-84.

Fraenkel, Ernst 1955-1965: Litauisches etymologisches Wörterbuch 1-2. Göttingen: Winter.

Gallén, Jarl 1984 (toim.): Suomen väestön esihistorialliset juuret. Tvärminnen symposiumi 17.-19.1.1980. Bidrag till kännedom av Finlands natur och folk H. 131. Helsinki: Societas Scientiarum Fennica.

Genetz, Arvid 1896: Ensi tavuun vokaalit suomen, lapin ja mordvan kaksi- ja useampitavuisissa sanoissa. - Suomi III: 13: 2-3. Helsinki: Suomalaisen Kirjallisuuden Seura.

Genetz, Arvid 1899: Vieläkin lapin sabme sanan mahdollisista suomalaisista vastineista. - Virittäjä 3: 107-108.

Grünthal, Villem 1910 = Grünthal, W.: Aruanne murde uurimiste üle Saaremaal. - Eesti Kirjandus V: 277-288.

Hackman, Alfred 1905: Die ältere Eisenzeit in Finnland I. Die Funde aus den fünf ersten Jahrhunderten n. Chr. Akademische Abhandlung. Helsingfors.

Hakulinen, Lauri 1934: Über die semasiologische Entwicklung einiger meteorologischaffektivischen Wortfamilien in den ostseefinnischen Sprachen. Studia Fennica I: 2. Helsinki.

Johansson, K. F. 1900: Anlautendes indogerman. b-. - Zeitschrift für vergleichende Sprachforschung auf dem Gebiete des Deutschen, Griechischen und Lateinischen. Band XXXVI: 342-390.

Joki, Aulis J. 1973: Uralier und Indogermanen. Die älteren Berührungen zwischen den uralischen und indogermanischen Sprachen. Suomalais-Ugrilaisen Seuran toimituksia 151. Helsinki: Suomalais-Ugrilainen Seura.

Junttila, Santeri 2005: Thomsenista Kalimaan. Vanhimpien itämerensuomalais-balttilaisten kielikontaktien tutkimus vuoteen 1936. Pro gradu -tutkielma Helsingin yliopiston suomalais-ugrilaiselle laitokselle. Helsingin yliopiston humanistisen tiedekunnan kirjasto. [http://urn.fi/URN:NBN:fi-fe20071167] 
Jõgever, Jaan 1910-1911: Eesti muinasajast. - Eesti Kirjandus V: 121-131; VI: 230-44.

Kalima, Jalo 1928: Eräiden sanojen alkuperästä. - Virittäjä 32: 102-111.

Kalima, Jalo 1933a: Virsi sanan alkuperästä. - Suomi 5: 16: 165-168. Helsinki: Suomalaisen Kirjallisuuden Seura.

Kalima, Jalo 1933b: Fi. sammas 'grenzstein'. - Finnisch-Ugrische Forschungen 21: 128137.

Kalima, Jalo 1934: Neue ansichten über die finnisch-baltischen berührungen. - FinnischUgrische Forschungen 22: 1-6.

Kalima, Jalo 1936: Itämerensuomalaisten kielten balttilaiset lainasanat. Suomalaisen Kirjallisuuden Seuran toimituksia 202. Helsinki: Suomalaisen Kirjallisuuden Seura.

Karsten, Tor Evert 1915: Germanisch-finnische Lehnwortstudien. Ein Beitrag zu der ältesten Sprach- und Kulturgeschichte der Germanen. Helsingfors: Druckerei der Finnischen Litteraturgesellschaft.

Karsten, Tor Evert 1922: Fragen aus dem Gebiete der germanisch-finnischen Berührungen. Översikt av Finska Vetenskaps-Societetens Förhandlingar LXIV. Afd. B. N:o 3. Helsingfors: Societas Scientiarum Fennica.

Karsten, Tor Evert 1926-1927: Zur Kenntnis der ältesten germanischen Lehnwörter des Ostseefinnischen (unter Berücksichtigung der iranischen und baltisch-slavischen Wörter) - Acta Philologica Scandinavica. Tidskrift for nordisk sprogforskning 1: 244-283.

Kock, Axel 1903: Om u-brytningen i fornnordiska språk. - Arkiv för Nordisk Filologi 19: 234-251.

Lidén, Evald 1897: Studien zur altindischen und vergleichenden Sprachgeschichte. Skrifter utgivna av K. Humanistiska vetenskapssamfundet i Uppsala; 6, 1. Uppsala: Almqvist \& Wiksell.

Lidén, Evald 1911: Baltisch-slavische worterklarungen. - Le Monde Oriental V: 197-204.

Liukkonen, Kari 1999: Baltisches im Finnischen. Suomalais-Ugrilaisen Seuran toimituksia 235. Helsinki: Suomalais-Ugrilainen Seura.

Loorits, Oskar 1929: Mõningad läti laensõnad eestis. - Eesti Keel VIII: 168-189.

Lõo, J. 1911: Meie koduloomade nimetused. - Eesti Kirjandus VI: 81-89.

Mikkola, Jooseppi Julius 1894: Berührungen zwischen den westfinnischen und slavischen Sprachen. I. Slavische Lehnwörter in den westfinnischen Sprachen. Suomalais-Ugrilaisen Seuran toimituksia VIII. Helsingfors: Suomalais-Ugrilainen Seura.

Mikkola, Jooseppi Julius 1906: Eräs baltilainen lainasana. - Virittäjä 10: 78.

Mikkola, Jooseppi Julius 1925: Kannel ja sen vastaava balttilainen nimitys. - Kalevalaseuran vuosikirja 5: 89-91.

Mikkola, Jooseppi Julius 1927: Vilhelm Thomsen ja suomalainen kielentutkimus. - Virittäjä 31: $297-299$.

Mikkola, Jooseppi Julius 1930 = Mikola, Joz: Vecākie sakari somu un baltu valodu starpā. - Izglìtības Ministrijas Mēnesraksts 1930. g. Rīga. 436-446.

Mikkola, Jooseppi Julius 1932: Paikannimien alalta III. - Virittäjä 36: 399-400.

Mikkola, Jooseppi Julius 1938: Die älteren Berührungen zwischen Ostseefinnisch und Russisch. Suomalais-Ugrilaisen Seuran toimituksia LXXV. Helsinki: Suomalais-Ugrilainen Seura.

Mägiste, Julius 1923: Etümologiseerimiskatseid. - Eesti Keel II: 33-39.

Mägiste, Julius 1925: Albert Saareste, Leksikaalseist vahekordadest eesti murretest. - Virittäjä 29: 86-91. 
Neuhaus, Johannes 1908: Kleine Finnische Sprachlehre nebst einem Wörterverzeichnis der finnisch-indoeuropäischen Entlehnungen. Heidelberg: Julius Groos Verlag.

Niemi, A. R. 1912: Eräs liettualainen lastenluku Suomessa. - Virittäjä 16: 1-9.

Nieminen, Eino 1934: Der stammauslaut der ins urfinnische entlehnten baltischen $\bar{a}$-feminina und die herkunftsfrage. - Finnisch-Ugrische Forschungen 22: 5-66.

Nieminen, Eino 1941: Prof. Kaliman vastauksen johdosta. - Virittäjä 45: 133-136.

Noreen, Adolf 1892: Altnordische Grammatik I. Altisländische und altnorwegische Grammatik unter berücksichtigung des Urnordischen. Zweite vollständig umgearbeitete Auflage. Halle: Max Niemeyer.

Noreen, Adolf 1903: Altnordische Grammatik I. Altisländische und altnorwegische Grammatik unter berücksichtigung des Urnordischen. Dritte vollständig umgearbeitete Auflage. Halle: Max Niemeyer.

Noreen, Adolf 1923: Altnordische Grammatik I. Altisländische und altnorwegische Grammatik (Laut- und Flexionslehre) unter berücksichtigung des Urnordischen. Vierte vollständig umgearbeitete Auflage. Halle(Saale): Max Niemeyer.

Ojansuu, Heikki 1899: Nimistä Suomi ja suomalainen, finne ja Finland. - Virittäjä 3: 81-91.

Ojansuu, Heikki 1921: Lisiä suomalais-balttilaisiin kosketuksiin. Vähäisiä kirjelmiä XLIX. Helsinki: Suomalaisen Kirjallisuuden Seura.

Paasonen, Heikki 1909a: Mordwinische Chrestomathie mit Glossar und grammatikalischem Abriss. Apuneuvoja suomalais-ugrilaisten kielten opintoja varten IV. Helsinki: Suomalais-Ugrilainen Seura.

Paasonen, Heikki 1909b: Eräs liettualaisperäinen sivistyssana. - Suomalainen Tiedeakatemia. Esitelmät ja pöytäkirjat 1. Helsinki: Suomalainen tiedeakatemia. 16-17.

Paasonen, Heikki 1917: Eräs liettualaisperäinen sana länsisuomalaisissa kielissä. - Virittäjä 21: 11-13.

Pipping, Hugo 1905-1907: Guta Lag och Guta Saga jämte ordbok. Utgifna för Samfund til udgivelse af gammel nordisk litteratur. København.

Porthan, Henrik Gabriel 1859: Opera Selecta. Pars Prima. Helsingfors.

Porthan, Henrik Gabriel 1873: Opera Selecta. Pars Qvinta. Helsingfors.

Rask, Rasmus Kristian 1818: Undersögelse om det gamle nordiske eller islandske sprogs oprindelse. Kjøbenhavn: Gyldendal,

Šahmatov, Aleksandr 1911= Шахматовъ, А. А.: Къ вопросу о финско-кельтскихъ и финско-славянскихъ отношеніяхъ I-II. - Bulletin de l'Académie Impériale des Sciences de St-Petersbourg 1911. С.-Петербургъ: Типографія Императорской Академіи наук.

Saxén, Ralf 1899: Kalpa sanasta. - Virittäjä 3: 43-44.

Setälä, Emil Nestor 1894: Berührungen zwischen dem Finnischen und Baltischen. - Archiv für slavische Philologie 16: 269-281. Berlin.

Setälä, Emil Nestor 1897: Suomalainen sana metu. - Virittäjä 1: 33-34.

Setälä, Emil Nestor 1899: Sabme - Häme. Pieni oikaisu. - Virittäjä 3: 109-10.

Setälä, Emil Nestor 1902: Zur etymologie von Sampo. - Finnisch-Ugrische Forschungen 2: 141-164.

Setälä, Emil Nestor 1907: Kullervo-Hamlet. Ein sagenvergleichender versuch. III. Die finnischen Kullervolieder. - Finnisch-Ugrische Forschungen 7: 188-264.

Setälä, Emil Nestor 1912: Aus dem gebiet der lehnbeziehungen. - Finnisch-Ugrische Forschungen 12: 161-289. 
Setälä, Emil Nestor 1932: Der älteste Germanenname im Finnischen - ein baltisches Wort? - Annales Academiae Scientiarum Fennicae B XXVII. Helsinki: Suomalainen tiedeakatemia. 396-408.

Smirnov, Ivan 1889 = Смирнов, И. Н.: Восточныля финны. Историко-этнографическія очерки. Казань.

SSA = Itkonen, Erkki \& Ulla-Maija Kulonen (toim.) 1992-2000: Suomen sanojen alkuperä. Etymologinen sanakirja 1-3. Suomalaisen Kirjallisuuden Seuran Toimituksia 556, Kotimaisten kielten tutkimuskeskuksen julkaisuja 62. Helsinki: Kotimaisten kielten tutkimuskeskus - Suomalaisen Kirjallisuuden Seura.

Streitberg, W. 1896: Urgermanische Grammatik. Einführung in das vergleichende Studium der altgermanischen Dialekte. Sammlung von Elementarbüchern der altgermanischen Dialekte I. Heidelberg: Carl Winters Universitätsbuchhandlung.

Suhonen, Seppo 1984: Lainasanat balttilais-itämerensuomalaisten kontaktien kuvastajina. - Jarl Gallén (toim.), Suomen väestön esihistorialliset juuret. Tvärminnen symposiumi 17.-19.1.1980. Bidrag till kännedom av Finlands natur och folk H. 131. Helsinki: Societas Scientiarum Fennica. 207-225.

Thomsen, Vilhelm 1869: Den gotiske sprogklasses indflydelse på den finske. En sproghistorisk undersøgelse. København: Gyldendalske Boghandel.

Thomsen, Vilhelm 1890: Beröringer mellem de finske og de baltiske (litauisk-lettiske) sprog: en sproghistorisk undersøgelse. København: Blanco Lunos.

Thomsen, Vilhelm 1919: Samlede Afhandlinger. Andet bind. København: Gyldendalske Boghandel.

Thunmann, M. Johann 1772: Ueber den Ursprung der alten Preussen und der übrigen lettischen Völker. - Untersuchungen über die alte Geschichte einiger Nordischen Völker 1. Berlin.

Toivonen, Yrjö Henrik 1917a: Etymologisia huomioita. - Virittäjä 21: 81-87.

Toivonen, Yrjö Henrik 1917b: Huomioita lainasanatutkimuksemme alalta. - SuomalaisUgrilaisen Seuran Aikakauskirja XXXIV,2.

Toivonen, Yrjö Henrik 1923: Ihmisestä, haamuista y. m. - Suomi V: 2: 368-379. Helsinki: Suomalaisen Kirjallisuuden Seura.

Toivonen, Yrjö Henrik 1924: Wortgeschichtliche streifzüge. - Finnisch-Ugrische Forschungen 16: 213-227.

Toivonen, Yrjö Henrik 1928: Über alter und entwicklung des ackerbaus bei den finnisch-ugrischen völkern. - Juhlakirja Yrjö Wichmannin kuusikymmenvuotispäiväksi. SuomalaisUgrilaisen Seuran toimituksia LVIII. Helsinki: Suomalais-Ugrilainen Seura. 229-240.

Toivonen, Yrjö Henrik 1931: Vaikku, vaikuttaa. - Sanakirjasäätiön toimituksia I. Helsinki: Suomalaisen Kirjallisuuden Seura. 31-36.

Tomaschek, Wilhelm 1883: Ethnologisch-linguistische Forschungen über den Osten Europa's. - Das Ausland. Stuttgart: Cotta. 701-706.

Tomaschek, Wilhelm 1889: Kritik der ältesten Nachrichten über den skythischen Norden II. - Sitzungsberichte der Philosophisch-historischen Classe der Kaiserlichen Akademie der Wissenschaften CXVII. Wien: Kaiserliche Akademie der Wissenschaften.

Tunkelo, Eemil Aukusti 1899: Mistä nimi Häme? - Virittäjä 3: 97-107.

Tunkelo, Eemil Aukusti 1928: Pari balttilaisperäiseltä näyttävää suomen sanaa. - Juhlakirja Yrjö Wichmannin kuusikymmenvuotispäiväksi. Suomalais-Ugrilaisen Seuran toimituksia LVIII. Helsinki: Suomalais-Ugrilainen Seura. 273-302. 
Waronen, Matti 1898: Vainajainpalvelus muinaisilla suomalaisilla. Suomalaisen Kirjallisuuden Seuran toimituksia 87. Helsinki: Suomalaisen Kirjallisuuden Seura.

Weske, Mihkel 1890 = Веске, М. П.: Славяно-Финскія культурныя отношенія по даннымъ языка. Извъстія Общества археологіи, исторіи и этнографіи при Императорскомъ Казанскомъ Университетъ. Томъ I, вып. 1. Казанъ: Типографія Императорскаго Университета.

Wiklund, Karl Bernhard 1896: Entwurf einer urlappischen lautlehre I. Einleitung, quantitätsgesetze, accent, geschichte der hauptbetonten vokale. Suomalais-Ugrilaisen Seuran toimituksia X,1. Helsingfors: Suomalais-Ugrilainen Seura.

Wiklund, Karl Bernhard 1900: Auhto sanan syntyperä. - Virittäjä 4: 40-44.

Wiklund, Karl Bernhard 1916: Om de västfinska folkens urhem och deras flyttning därifrån. - Le Monde Oriental X: 165-179.

Zinkevičius, Z. \& Kabelka, J. 1958: Kazimieras Būga. - Būga, Kazimieras: Rinktiniai raštai I. Vilnius: Valstybinė politinès ir mokslinès literatūros leidykla. 13-100. 


\section{Liite}

Luettelo itämerensuomalais-balttilaisten kontaktien tutkijoista ajanjaksolla 1869-1936 ja näitten muinaisbalttilaisina lainoina esittämät etymologiat, joita Suomen sanojen alkuperä (SSA) pitää varmoina tai mahdollisina.

Vilhelm Thomsen (1842-1927): (1869) ankerias, halla, hammas, hanhi, harja, heinä, herne, kaula, keli, kirves, kärme, laiha, lohi, ?metsä, morsian, oinas, ?olut, paimen, ?parta, ratas, ?ruis, seinä, siemen, sisar, ?taimi, taivas, tarha, terva, tuhat, tyhjä, tytär, ?vaaja, villa, vuohi ja ve kurdiš va kurre vi kurt 'kuuro', (1890) aarto, ?ahdas, ?ahingas, ??ahven, ?aina, ?apila, haljakka, ?halli, ?halme, herhiläinen, hirvas, hirvi, ?härkä, härmä, ?irta-, ??jo, ?juhta, ?kaikki, ?kannel, ?karsas, karva, ?karvas, ?karve, ?kauru, kela, ?kinnas, ?kulo, kypärä, ?käki, lahto, ?lauta, ?liika, ?liiva, ?louhia, meri, muli, ?märkä, nepaa, niisi, ??nukero, ?nuode, pelu, ??peura, puuro, rako, reisi, reki, rieska, rihma, routa, salo, seiväs, ?tapa, ?tarpoa, tarvas, ?teeri, temmata, toe, torvi, tuulas, tuura, vaapsahainen, vaha, ??varsi, ?varsta, vielä, vihvilä, ?virpa, ?virta, vuota, väive ja ätelä

József Budenz (1836-1892): (1873) silta, (1875) harmaa, mäntä

Otto Donner (1835-1909): (1884) ansa, harakka, heimo, hihna, jäärä, kaima, ?karpio, karta, ?kataja, kauha, kelta, kurpponen, ?laiska, laukki, luuta, ?maja, malka, ?napa, panu, perkele, rastas, seura, takiainen, talkoot, taula, tuohi, vako, virpi ja ?äes

Nikolai Anderson (1845-1905): (1893) ?lunka, (1896) ?Häme

Emil Nestor Setälä (1864-1935): (1894) ?kaarna, (1897) ?metu, (1912) ?kurko

Jooseppi Julius Mikkola (1866-1946): (1894) ?hako, ?karsta, (1906) kiiliäinen

Karl Bernhard Wiklund (1868-1934): (1896) ?lava, rieska

Evald Lidén (1862-1939): (1897) ?aisa, (1911) ?aitta

Matti Waronen (1861-1911): (1898) ?kouko

Ralf Saxén (1868-1932): (1899) ?kalpa

Eemil Aukusti Tunkelo (1870-1953): (1899 Andersonista tietämättä) ?Häme, (1928) karsina, ?luoma

Kazimieras Būga (1879-1924): (1908) ?hirsi, ketara, ?leuka, ?luoma, puusniekka, reuna

Heikki Paasonen (1865-1919): (1909a) ?liika, (1909b) ??vannas, (1917) ?vuona

Jaan Lõo (1872-1939): (1911) ??tiine

Yrjö Henrik Toivonen (1890-1956): (1917a) ?mytyri, (1917b) ?kampi, (1923) ?kääppä, (1924) ?vinka 'koukku', (1931) ?vaikku

Heikki Ojansuu (1873-1923): (1921) ?hako, helle, ?jutta, ?kelle, kupo, ohra, ??parjata, ??rahtu, rainta, ??särpiä, ?vaidella

Julius Mägiste (1900-1978): (1923) ?kutsua, (1925) ??vinka 'häkä'

Oskar Loorits (1900-1961): (1929) malo

Jalo Kalima (1884-1952): (1928) pahla, (1933a) orsi, virsi, (1933b) sapa, (1936) ?elki elje, ?hautoa, ?havu, ??jäytää, ??kina, ??kiuru, ??ranka, ??rouhia, sakara, vohla, vi paun

Eino Nieminen (1891-1962): (1934) ?näivä

Lauri Hakulinen (1899-1985): (1934) ?kaarita 
Santeri Junttila $<$ santeri.junttila@helsinki.fi>

Suomalais-ugrilainen laitos

PL 25

00014 Helsingin yliopisto 